\title{
Causal Relationship between Foreign Direct Investment and Economic Growth in Nigeria: 1970-2013
}

\author{
Uwazie, I. U. ${ }^{1}$, Igwemma, A. A. ${ }^{2} \&$ Nnabu Bernard Eze ${ }^{3}$ \\ ${ }^{1}$ Department of Economics, Alvan Ikoku University of Education, Owerri, Nigeria \\ ${ }^{2}$ Department of Economics, Imo State University, Owerri, Nigeria \\ ${ }^{3}$ Department of Economics, Ebonyi State University, Abakiliki, Nigeria \\ Correspondence: Nnabu Bernard Eze, Department of Economics, Ebonyi State University, Abakiliki, Nigeria.
}

Received: August 20, 2015

Accepted: September 16, 2015

Online Published: October 25, 2015

doi:10.5539/ijef.v7n11p230

URL: http://dx.doi.org/10.5539/ijef.v7n11p230

\begin{abstract}
Foreign direct investment is presumed to play immense role in economic growth in both developed and developing economies. This assumption has motivated the army of studies to actually determine the nexus between foreign direct investment and economic growth in Nigeria. But these studies were not unified on the direction of the causation, hence the need for the study. To effectively analyze the result, the study employs vector error correction model method of causality to analyze the annual data for the periods of 1970 to 2013 . The Augmented Dickey-Fuller (ADF) unit root test show presence of unit root at level but stationary after first difference. The Johansen cointegration test confirms that the variables are cointegrated while the granger causality test affirms that foreign direct investment and economic growth reinforce each other in the short run in Nigeria. Also, it is reported that foreign direct investment granger cause economic growth both in the short and long run in Nigeria. Based on these findings, the study advocates the adoption of aggressive policy reforms to boost investors' confidence and promotion of qualitative human capital development to lure FDI into the country. It also suggests the introduction of selective openness to allow only the inflow of FDI that have the capacity to spillover to the economy. These will attract FDI and boost economic growth in Nigeria.
\end{abstract}

Keywords: FDI, GDP, causality, VECM

\section{Introduction}

Achieving sustainable economic growth has been the major problem facing many developing countries including Nigeria. On attaining independence in 1960, Nigeria in her quest to achieve rapid economic growth departed from pre-independence private sector-led economy to active government participation in economic activities. Government embarked on aggressive indigenization policy which was embedded in the Second Development Plan of 1972. This policy restricted foreign involvement in commerce and manufacturing sector to 60 percent. It was further reduced to 40 percent by the second indigenization decree of 1977 . These policies drastically reduced foreign involvement in business activities in Nigeria. To this end, government nationalized foreign-owned enterprises and actively engaged in establishment of industries such as petroleum and petrochemical industries, agro-industries, diversification of textile industries, iron and steel industries and installation of car assembly companies. The establishment of these projects were necessitated by oil boom of 1973 to 1975 . These were necessitated by the oil boom of 1973 to 1975 . But, these poorly conceived policies negatively affect the free flow of foreign direct investment into the country (Rodrick, 1998).

By 1980's, government could no longer fund these projects due to oil glut that characterized this period. The economy suffered serious setback as a result of the poor returns of these projects. In fact, most of the companies were moribund or producing at quarter capacity (Egeonu, 2005). This enables government to realize that private sector plays important role on economic growth and development. The quest for foreign direct investment stem from the assumption that it not only provides the economy with the much need capital but also enhance job creation, boost managerial skill, bolster business competition, create export as well as transfer of technology (Obida \& Nurudeem, 2010, Nabila, Samia, \& Hafeez, 2011; and Abdullahi, Aliero, \& Yusuf, 2012). In their separate studies, Mercinger (2003) and Bello and Adeniyi (2010) asserted that foreign direct investment does not have positive spillover effect on economic growth but rather force out domestic firms thus reducing competition. 
Foreign direct investment has been seen as the driving force for economic growth and development in Nigeria. Its inflow has been on increase since the economic reform of 1986. The foreign direct investment increased from 193.2 million dollars in 1986 to 1874.04 billion in 2002. For the periods of 2003 to 2013, it further rose from 2005.4 billion dollars to 5609 billion dollars. The inflow of FDI as the percentage of GDP increased from 0.93 percent in 1986 to 5.05 percent in 2009 but later declined to 1.64 in 2010 and 1.07 percent in 2013 (UNCTAD, 2015). The growth rate of the GDP has declined from 8.3 percent in 1985 to -8.8 percent in 1986 and -10.8 in 1987 but from 2003 to 2013, the economy witness unprecedented increase in economic growth averaged 6 to 7 percent per annum (CBN, Annul Reports, 2011 and IMF, 2012). Despite these impressive rises in economic growth and inflow of FDI for more than two decade in Nigeria, these have not trickled down to the sectors of the economy. For instance, the poverty rate has been on increase. It rose from 54.7 percent in 2004 to 60.9 percent in 2010 while unemployment rate skyrocketed from 11.8 percent in 2004 to 24.3 percent in 2012 (NBS, 2012). Based on these, it becomes necessary to determine the causal relationship between FDI and economic growth in Nigeria. The question is does FDI causes economic growth or does a growing economy attracts the FDI inflow?

There has not been any consensus view on the direction of the causality between FDI and economic growth of Nigeria despite the enormity of the previous studies. For instance, Ogundipe and Aworinde (2011) asserted a one-way causality run from economic growth to FDI. To William (2012), FDI is responsible for recent economic growth of Nigeria. Okon, Augustine and Chukwu (2012) maintained that FDI and economic growth reinforce each other in Nigeria while Yaqub, Adam and Jimoh (2013) put it that FDI does not lead to increase in economic growth in Nigeria. These serve as a motivation for this study.

\section{Theoretical Literature Review}

Classical theory is of the view that foreign direct investment plays important role in economic growth of the host countries (Lensink \& Morrissey, 2001, and Gorg \& Strobl, 2002, Nabila, Samia, \& Hafeez, 2011, Oyatoye et al., 2011). According to the theory, FDI through positive spillover, competition and imitation enhance the transfer of capital, technology and skills to the host countries (Mody, 2004; and Gao, 2005). Also, through backward and forward linkage FDI will lead to improved balance of payments, boost the gross national income, enhance improvement in infrastructure and increases the production for export (Gorg et al., 2001, Girma et al., 2003, Li \& Liu, 2005, Chakraborty \& Nunnenkamp, 2008, and Obida \& Nurudeem, 2010).

Dependent theory did not believe on the assumption that FDI is vital for the economic growth of developing countries. The theory posits that FDI strangulate development by displacement of indigenous production and perpetuates dominance of the weaker countries by keeping them in a position of constant dependence on the economies of the developed countries (Alfaro, 2003; UNCTAD, 1999, Gorg \& Strobl, 2002, and Girma \& Wakelin, 2000; Mercinger, 2003; and Bello \& Adeniyi, 2010).

The intervention or integrative theory calls for mixture of both the classical and dependency theories. It cautions against too much openness and too much regulation or intervention (Seid, 2002). It maintains that there are instances where the market is better placed to act and other instances where government intervention is necessary.

New growth theory or endogenous theory sees the level of technology as a driving force for a long run economic growth in any economy. According to the theory, knowledge and technology result to increase in return which lead to increase in economic growth (Cortright, 2001). In production function, Meier and Rauch (1995) pointed out that human capital investment contributes to increase in return while De Castro (1998) put it that the level of research and development in an economy will determine the rate of innovation and economic growth of the country. By augmenting domestic capital and incorporation of diffused foreign technologies in the production function of the host countries, foreign direct investment will be seen as responsible for increase in economic activities in the host economy (Shan, Tian, \& Sun, 1997).

\section{Empirical Literature Review}

Previous empirical studies have divergent views on the role FDI in enhancing economic growth. Some of these studies such as Magnus and Fosu (2007) used Toda-Yamamoto and granger causality on annual data range of 1970 to 2001 to analysis FDI as it affect pre and post SAP economic growth of Ghana. The results of the study failed to establish the evidence of causality between FDI and economic growth for the whole period and pre-SAP period. Also, the result indicated that FDI granger caused economic growth within post-SAP period. In a similar study of China, Sumei, and Selvanathan (2008) also employed Granger causality test on time series data between the periods of 1988 to 2003. The result reported a one-way causal link from FDI to domestic investment and to economic growth. The study further confirms evidence of a two-way causal between domestic investment and economic growth. 
Abdus (2009) adopted co-integration approach in his analysis of the nexus between FDI and growth of 19 selected developing countries. The result established that growth of the economy granger cause FDI in 5 economies. The study also, confirms evidence FDI and growth granger cause each other in seven countries. In the short run, the study reveals that growth granger cause FDI in four economies.

In Malaysia, Karimi and Yusop (2009) employed Toda-Yamamoto granger causality test to analyze the causal link between FDI and growth for the periods of 1970 and 2005. The study reported a foreign direct investment and growth granger cause each. Also the study shows evidence of cointegration between foreign direct investment and output. In India, a similar study by Chakraborty and Nunnenkamp (2008) used a panel co-integration test approach to examine the sectoral impact of FDI on post-reform economy. The study stated the absence of causation in the primary sector while FDI and output reinforce each other in the manufacturing sector. Also, it reveals that FDI in service sector granger cause output of manufacturing sector. In a similar study on India for the periods of 1980 to 2010, Zafar (2013) reported that foreign direct investment leads to long run growth of export. The causality test indicated a one-way causality from export to foreign direct investment. Finally, the result reported no causality between export and foreign direct investment in the short run.

Nabila, Samia, and Hafeez (2011) employed heterogeneous panel techniques on annul data for the periods of 1983-2008 to examine the impact of foreign direct investment on economic output of selected Asian countries. The Larsson panel test shows evidence that foreign direct investment and economic growth are co-integrated. FMOLS posited that FDI has positive significant impact on economic growth. The panel homogeneous causality shows that foreign direct investment and output granger cause each other but non-causality test affirms evidence of uni-directional causal relationship run from foreign direct investment to output of the selected economies. In the case of Malaysia, the test exhibits that foreign direct investment and growth have two-way causation. The results show that foreign direct investment granger cause economic growth of Thailand, Singapore, Nepal, and Japan while in Sri-Lanka, Pakistan and Bangladesh economic growth granger cause foreign direct investment. Finally, the study did not show any causation in the case of Singapore, China, and Maldives, Korea Democratic, Indonesia, Philippines and India. In a similar study in selected African and Asian countries, Abdullahi, Aliero and Yusuf (2012) and Gaurav and Mohd (2011) reveal that FDI positively impact on economic growth in African and Asian countries. The study also reported a one-way relationship from FDI to economic growth only in Africa.

In the study of the causal relationship between FDI, trade and economic growth of Pakistan from 1998 to 2009 using VECM approach, Muhammad, Faiz, and Amir (2010) established presence of co-integration among the variables. Granger causality result reveals that FDI, export and output reinforce one another. The result concluded that FDI positively impact on the trade and output of Pakistan.

In Nigeria many scholarly studies have been carried out to on the impact and directional relationship between FDI and growth of the GDP. For instance, Olusegun, Oluwatosin, and Ayoola (2009) employed ARDL techniques to examine how FDI, openness relate to economic growth for the periods 1970 to 2006. The result reveals FDI granger cause economic growth in Nigeria. In a related study, Ajibola and Olufemi (2011) reveal evidence of long run relationship between financial development, FDI and growth. Also, the study found out that one-way causation run from financial development, FDI and economic growth. Hence the study concludes that financial development and foreign direct investment play important role in economic growth of Nigeria.

William (2012) in his study of the directional link among FDI, exports and economic growth from 1960-2009 using VECM found out that foreign direct investment plays important role in boosting export in the long run wile GDP and exports reinforce each order in the short run. Also, the study reported that foreign direct investment granger cause exports and GDP. Ogiagah, Parker, and Shaib (2011) investigated the impact of foreign direct investment inflow from Ghana and South Africa on Nigerian economy from 1979 to 2007 using VAR bound techniques. The Granger test revealed that GDP in Nigeria granger cause long-run foreign direct investment inflow to Nigerian economy.

Innocent, Nkechinyere, Ebele, and Nzeribe (2012) used OLS and granger regression equations to empirically examine the nexus between foreign direct investment and growth rate of GDP in Nigeria from 1986 to 2010. The result indicated that FDI has insignificant impact on economic growth. It also reported that FDI and GDP granger cause each order. Ade, Babatunde, and Awoniyi (2011) in their study of corruption as it affect inflow of foreign direct investment in Nigeria employed OLS and granger causality techniques on data covering 1990 and 2009. The result shows evidence of cointegration between inflow of FDI and low corruption level. The OLS result reveals the corruption has negative impact with FDI inflow in Nigeria while FDI has positive impact on economic growth. The study identifies that exchange rate and inflation rate are significantly determine the inflow 


\section{of FDI in Nigeria.}

Eravwoke and Eskanake (2012) applied OLS and VAR techniques to test the direction relationship between FDI and output growth of Nigeria from 1970-2009. It reveals that causation does not run from GDP to FDI. Similarly, Bello and Adeniyi (2010) using ARDL techniques on annual data from 1970 to 2006 finds no presence of co-integration between foreign direct investment and GDP while environmental quality granger cause long-run inflow of foreign direct investment.

Ogundipe and Aworinde (2011) ecplored the possible relationship between foreign direct investment and GDP in pre and post deregulation period in Nigeria employing VAR techniques. The study reveals that GDP granger cause FDI within the pre deregulation period of 1970 and 1985 while it reported no causation within the post deregulation period of 1986 to 2007. Okon, Augustine and Chukwu (2012) employed single and simultaneous equation systems in the examination of FDI and GDP growth within the period of 1970 to 2008. It is reported that foreign direct investment and GDP granger cause each other in Nigeria.

Samuel and Victor (2012) examine the determinants of foreign direct Investment in Nigeria from 1970-2010 using ECM. The parsimonious ECM result proves that market size, inflation, trade liberalization, real exchange rate are significant determinants of FDI while economic growth does not determine foreign capital inflow. The co-integration test reveals that all the variables are co-integrated in Nigeria. Oyatoye, Arogundade, Adebisi and Oluwakayode (2011) employed OLS techniques in their analysis of the effect of FDI on GDP growth for the period of 1989-2006. The result maintained that FDI has positive impact on GDP in Nigeria. Babatunde, John and Samuel (2012) employed Generalized Method of Moments to analyse the locational effect on FDI inflow to Nigeria from 1975-2005. The result shows that government expenditure, energy consumption and political stability determine foreign direct investment in Nigeria.

Adegbemi (2012) studied FDI as it relate to GDP growth in Nigeria for the period 1970-2010 with the help of a three-stage least square (3SLS). The result opines that foreign direct investment leads to growth but varies across sectors. Egwaikhide (2012) applied cointegration VECM approach to examine the effect of FDI and growth of GDP in Nigeria from 1980-2009. The cointegration test reveals FDI agriculture; mining, manufacturing and petroleum sectors impact little on growth while foreign direct investment to telecom sector impact heavily in the long run. Also, the study affirms that FDI and infrastructures reinforce each other. Yaqub, Adam and Jimoh (2013) investigated FDI and economic growth in Nigeria from 1980 to 2006 using VAR approach. The result reveals that there is no causal relationship between FDI and economic growth in Nigeria. Moreover the study failed to identify FDI as a determinant of economic growth in Nigeria. It finally concludes that GDP growth rate is determined by its own shocks.

\section{Summary of Reviewed Empirical Review}

The argument against some of the previous studies such as Nabila et al. (2008), Abdus (2009), Ogiagah et al. (2011) and Abdullahi et al. (2012) are cross-country studies. However, Chowdhury and Mavrotas (2005) proposed that every country should carry out her own study to ascertain the direction of the relationship. Some other studies such as Magnus and Fosu (2007), Sumei and Selvanathan (2008), Karimi and Yusop (2009), Chakraborty and Nunnenkump (2008), Zafar (2013), Muhammad et al (2010) were carried out in other countries and need to be replicated in Nigeria.

Another problem is that some of these studies such as Olusegun et al. (2009), Bello and Adeniyi (2010), Ajibola and Olufemi (2011) and William (2012) either used a simple two-variable or three-variable model relationship. Gujarati (1995) pointed out that the result of granger causal relationship analysis depends on the functional form and lag length. Therefore, analysing causality with simple three-variable model or less may to specification error.

Study such as Oyatoye et al (2011) failed to consider the endogenous nature of a production function as argued by Ajibola and Olufemi (2011) and Innocent et al. (2012). Such study may lead to simultaneity error. Gujarati (1995) highlighted that VAR or VECM model is more appropriate since it considers the endogeneity of production function (Gujarati, 1995).

Some other studies after establishing evidence of cointegration went further to use pair-wise (VAR) granger causality instead of VECM. Such studies include Olusegun et al. (2009), Ogundipe and Aworinde (2011), Ade et al. (2011), Innocent et al. (2012), Eravwoke and Eskanake (2012), Egwaikhide (2012), and Yaqub, Adam and Jimoh (2013). The idea of using VAR or pair-wise granger causality after establishing presence of co-integration may lead to spurious regression. Studies such as Samuel and Victor (2012), Babatunde et al. (2012), Adegbemi (2012) and Egwaikhide (2012) focused either on impact or determinants of foreign direct investment on GDP growth without reference to the causal relationship. 
This study is different from these previous studies based on the fact that it adopted vector error correction model based granger causality test. The choice of this method is based on the fact that it considers the endogeneity of the production exhibited by the evidence of cointegration among the variables of this study. Moreover, it distinguishes between short run and long run causality which the VAR approach fails to detect. Also, variables such as government capital expenditure on construction as proxy for infrastructure and national savings as proxy for domestic investment were included in the model and the data for the analysis extended to 2013.

\section{Methodology}

\subsection{Model Specification}

The theoretical framework is based on new growth theory or neoclassical Solow production function. The theory posits that the spill over effect such as knowledge and the level of technology drive the growth process (Cortright, 2001). In production, human capital investment characterizes increase in returns (Meier \& Rauch, 1995). According to theory, growth is a function of capital accumulation, an expansion of labour force and technological progress which makes physical capital and labour more productive. Thus, the production function is specified as

$$
Y_{t}=K_{t}^{\alpha} L_{t}^{\beta}\left(A_{t}\right)
$$

Where $Y_{t}$ is aggregate output, $K_{t}$ is capital stock, $A$ is the technological level, $t$ is time period, $L$ is labour. But capital stock $(\mathrm{K})$ is disaggregated into physical capital $\left(\mathrm{K}_{\mathrm{pt}}\right)$ and human capital $\left(\mathrm{K}_{\mathrm{ht}}\right)$. Therefore, equation 1 is modified as:

$$
Y_{t}=\left(K_{p t}+K_{h t}\right)^{\alpha} L_{t}^{\beta}\left(A_{t}\right)
$$

Physical capital $\left(\mathrm{K}_{\mathrm{pt}}\right)$ is further disaggregated into FDI $\left(\mathrm{K}_{\mathrm{pf}}\right)$ and domestic investment $\left(\mathrm{K}_{\mathrm{pd}}\right)$. Equation 2 is modified to incorporate FDI $\left(\mathrm{K}_{\mathrm{pf}}\right)$ and domestic investment $\left(\mathrm{K}_{\mathrm{pd}}\right)$ as

$$
Y_{t}=\left(K_{p f t}+K_{p d t}+K_{h t}\right)^{\alpha} L_{t}^{\beta}\left(A_{t}\right)
$$

Transforming the equation 3 in logarithm form

$$
\log Y_{t}=\alpha \log K_{p f t}+\alpha \log K_{p d t}+\alpha \log K_{h t}+\beta \log L_{t}+\log A_{t}
$$

Where $\alpha=\alpha_{1}, \alpha=\alpha_{2}, \alpha=\alpha_{3}, \beta=\alpha_{4}$ and $\log \mathrm{A}_{\mathrm{t}}=\alpha_{0}$.

To achieve the objectives of this study, equation 4 is further modified to incorporate additional variables such as level of infrastructure and trade openness. This is due to their roles in influencing the flow of FDI to an economy. The model for the study is specified as

$$
\log G D P_{t}=\alpha_{0}+\alpha_{l} \log F D I_{t}+\alpha_{2} \log H M C_{t}+\alpha_{3} \log E T R_{t}+\alpha_{4} \log C O N S_{t}+\alpha_{5} \log O P N_{t}+e_{t}
$$

Where GDP is gross domestic product, FDI is foreign direct investment, HMC is human capital, ETR is electricity supply, CONS is construction, OPN is openness, $\mathrm{a}_{0} \ldots, \mathrm{a}_{5}$ represent the explanatory powers of the variables, $\mathrm{e}_{\mathrm{t}}$ is the stochastic error term.

\subsection{Variable Discussion}

GDP is gross domestic product at current basic prices, FDI is the inflow of foreign direct investment in terms of naira, HMC is human capital measured by recurrent expenditure on health and education, ETR is Electricity supply measured as percentage of consumption (megawatt per hour), CONS is construction measured by recurrent expenditure on construction and OPN is the level of trade openness measured as import plus export divided by GDP. All the variables are expected to show positive relationship with economic growth.

\subsection{Estimation Procedures}

\subsubsection{Unit Root Test}

The researcher begins the estimation with the test of unit root test to determine whether the variables are stationary using Augmented Dickey- Fuller (ADF). The ADF $\tau$ (tau) statistic, which its variable is based on the Monte Carlo simulations, is performed in the following model.

$$
\Delta \mathrm{Yt}=\alpha+\rho_{\mathrm{t}}+\beta \mathrm{Y}_{\mathrm{t}-1}+\lambda \sum_{i-1}^{m} \mathrm{Y}_{t-i}+\varepsilon_{\mathrm{t}}
$$

Where $\Delta$ represent first difference, $\mathrm{Y}$ is the variable to be tested, $\mathrm{t}$ is time or trend and $\varepsilon$ is the stochastic error term. The null hypothesis is rejected if the tau statistic $|\tau|$ is greater that the critical values and conclude that the variables are stationary. But the null hypothesis of unit root is accepted if tau statistic is less than the critical value and concludes that the variables have unit root or non-stationary. 


\subsubsection{Co-Integration Test}

Since all the variables are integrated of the same order, it is important to determine the whether the variables are cointegrated or not. To do this, the study employs Johansen-Juselius maximum likelihood method of co-integration. If our model is co-integrated, then VECM, a restricted form of VARs will have to be used but if not, we continue with the unrestricted model. If co-integrated, the implication is that all the variables share a common stochastic trend and will grow proportionally, in order words, a long run relationship exist amongst them. The JJ maximum likelihood test will be done on the variables in their non-stationary form.

$$
\begin{gathered}
\Lambda_{\text {trace }}=-T \sum_{i=r+1}^{n} \operatorname{In}\left(1-\lambda_{i}\right) \\
\Lambda_{\max }=-T \operatorname{In}\left(1-\lambda_{r+1}\right)
\end{gathered}
$$

Where $\lambda$ trace represent trace statistic, $\lambda$ max stand for eigen-max statistc, $\lambda 1$ represent eigen-values, and $\mathrm{T}$ means sample size. The null hypothesis of no cointegration $r=0$ is rejected if the trace or maximum eigenvalue statistics is greater than the critical value at 5 percent level of significance. Equal number of CEs or equal number of rejections supports for VECM while unequal number of CEs or rejections supports VAR.

\subsubsection{Vector Error Correction Model}

Since single equation model such as equation 5 does not necessarily imply the direction of causation or explain the interdependence that may exist between the explanatory variables themselves or how they relate to other variables (Adeleke, 2013). Therefore, study employs Granger causality based on VECM to determine the direction of causation. The VECM is preferred to the pair-wise (VAR) causality, since the variables are cointegrated. This renders the choice of VAR useless as used by Olusegun et al. (2009), Ogundipe and Aworinde (2011), Ade et al. (2011), Innocent et al. (2012), Eravwoke and Eskanake (2012), Egwaikhide (2012), and Yaqub, Adam, and Jimoh (2013) in their study of Nigeria. Thus the choice of VECM based causality test. The VECM classifies causality into short run and long run causation which is totally ignored by VAR or pair-wise causality test. The significance of t-statistic of ECTs signifies long run causality while the significance of F-statistic of the lagged parameters indicates the presence of short run causality (Masih \& Masih, 1996, 1997 and 1998).

In the study, GDP and FDI are expected to have a causal relationship as indicated by the equations below:

$$
\begin{aligned}
& \begin{array}{cccccc}
P & p & p & p & p & p \\
\Delta G D P_{t}=\alpha_{1}+\sum \beta_{i} \Delta G D P_{t-I} & +\sum \gamma_{l j} \Delta F D I_{t-i}+\sum \delta_{l} \Delta H M C_{t-i}+ & \sum \lambda_{i} \Delta E T R_{t-i}+\phi_{l} \Delta C O N S_{t-i}+\sum_{l} \Delta O P N_{t-i}+\theta_{l} E C T_{t-l}+\varepsilon_{l t} \\
i=1 & i=1 & i=1 & i=1 & i=1 & i=1
\end{array} \\
& \begin{array}{rrrrr}
p & p & p & p & p
\end{array} \\
& \Delta \mathrm{FDI}_{\mathrm{t}}=\alpha_{2}+\sum \beta_{2 \mathrm{i}} \Delta \mathrm{FDI}_{\mathrm{t}-\mathrm{i}}+\sum \gamma_{2 \mathrm{i}} \Delta \mathrm{GDP}_{\mathrm{t}-\mathrm{i}}+\sum \delta_{2 \mathrm{i}} \Delta \mathrm{HMC}_{\mathrm{t}-\mathrm{i}}+\sum \lambda_{2 \mathrm{i}} \mathrm{ETR}_{\mathrm{t}-\mathrm{i}}+\sum \phi_{2 \mathrm{i}} \Delta \mathrm{CONS}_{\mathrm{t}-\mathrm{i}}+\Sigma \Omega_{1} \Delta \mathrm{OPN}_{\mathrm{t}-\mathrm{i}}+\theta_{2} \mathrm{ECT}_{\mathrm{t}-1}+\varepsilon_{2 \mathrm{t}} \\
& i=1 \quad i=1 \quad i=1 \quad i=1 \quad i=1
\end{aligned}
$$

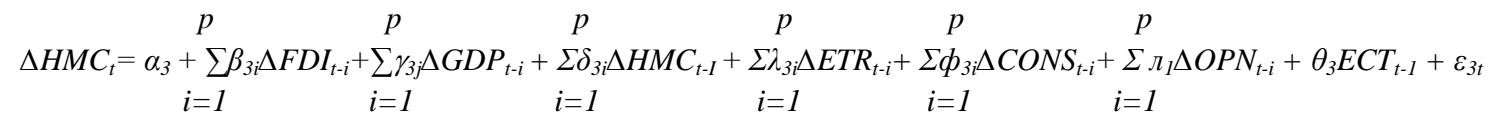

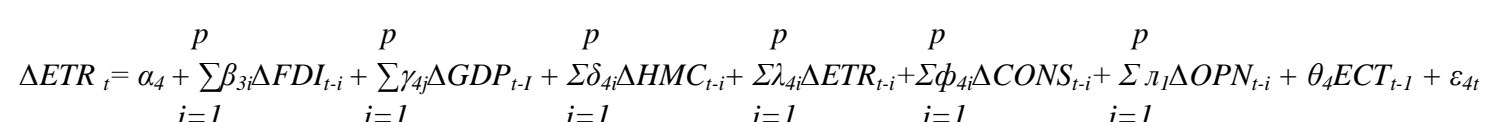

$$
\begin{aligned}
& i=1 \quad i=1 \quad i=1 \quad i=1 \quad i=1
\end{aligned}
$$

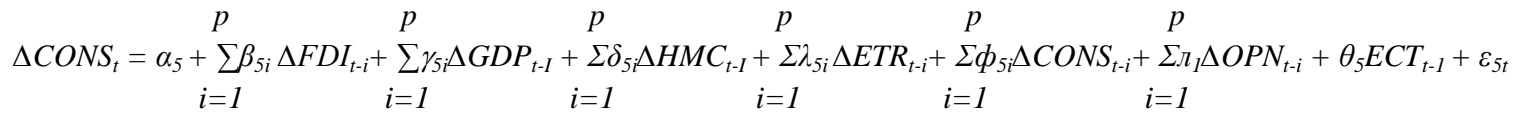

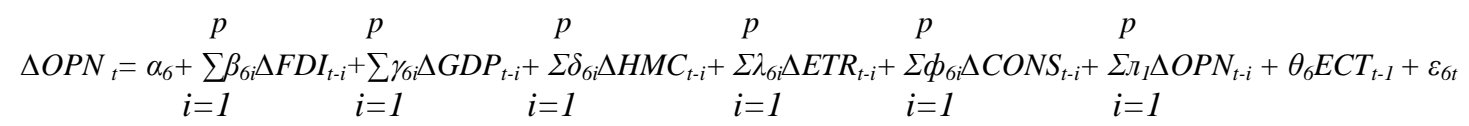

Where GDP represent gross domestic product, FDI, HMC, ETR, CONS and OPN represent foreign direct investment, human capital, electricity consumption, electricity, construction expenditure and openness respectively. $\Delta$ denotes first difference. The ECT is the error correction terms, which shows the speeds of adjustment to the long run equilibrium. The p's represent the lag length while $\alpha$,'s represent the coefficients. The maximum lag length, $\mathrm{p}$, is empirically determined using the Akaike Information Criterion (AIC).

In each model, the dependent variable is run against its lagged value and the lagged values of other explanatory variables. However, equation 7 determines the causality from GDP to FDI. Equation 8 tests causality from FDI 
to GDP. Equation 9 tests causation from human capital to FDI, equation 10 tests causality from electricity consumption to FDI, equation 11 tests causality from construction to FDI, whereas equation 12 tests causality from openness to FDI.

\subsection{Sources of Data}

The data required for this research are secondary data on FDI, GDP, human capital expenditure, electricity consumption, and construction expenditure and trade openness. Data such as FDI, GDP, human capital expenditure and construction expenditure were obtained from CBN Statistical Bulletin, 2009, 2013 and 2014. Data on electricity consumption sourced from International Energy Statistics, 2012 while openness calculated from import and export data obtained from CBN Statistical Bulletin 2010 and 2014.

\section{Result Presentation}

\subsection{Unit Root Test Result}

The result of the Augmented Dickey Fuller unit tests are presented in table 1 below. The test indicated all the variables have unit root at levels, since their respective ADF statistics are much less than the critical values. These are supported by their p-values which are greater than 0.05 levels. However, all the variables proved to be stationary after first differencing, since the ADF statistics are much more than their respective critical values. This was proven their respective p-values which are less than 0.05 . The study conclude that all the variables are integrated to order one I(1).

Table 1. Augmented Dickey-Fuller unit root test results

\begin{tabular}{cccccccc}
\hline & \multicolumn{3}{c}{$\mathbf{5 \%}$} & \multicolumn{3}{c}{$\mathbf{1}^{\text {st }}$} & \multicolumn{3}{c}{$\mathbf{5 \%}$} \\
\cline { 2 - 8 } Variable & Level & critical value & P-value & Difference & critical value & p-value & Decision \\
\hline GDP & 2.340206 & -3.518090 & 1.0000 & $-5.328017^{*}$ & -3.520787 & 0.0000 & $\mathrm{I}(1)$ \\
FDI & -0.721536 & -3.518090 & 0.9649 & $-6.415196^{*}$ & -3.520787 & 0.0000 & $\mathrm{I}(1)$ \\
HMC & 1.609342 & -2.933158 & 0.9993 & $-8.372316^{*}$ & -2.933158 & 0.0000 & $\mathrm{I}(1)$ \\
ETR & -2.502961 & -3.518090 & 0.3252 & $-9.159742^{*}$ & -3.520787 & 0.0000 & $\mathrm{I}(1)$ \\
CONS & 0.241592 & -3.520787 & 0.9976 & $-9.590323^{*}$ & -3.520787 & 0.0000 & $\mathrm{I}(1)$ \\
OPN & -0.584688 & -1.948886 & 0.4581 & $-9.944900^{*}$ & -1.948886 & 0.0000 & $\mathrm{I}(1)$ \\
\hline
\end{tabular}

Note. * indicates significance at 5 percent level.

Source: Researcher's computation, 2015, using E-view 7.0.

\subsection{Co-Integration Test Result}

The evidence of variable being integrated to order one I(1) drives the test of presence of co-integration between FDI and economic growth in Nigeria. Given the sample size of 44 years, the lag length chosen to be one (1), the results show evidence of co-integration at 5 percent level of significance as suggested by the trace statistics and maximum eigen statistics. The results are presented in table 2 below.

Table 2. Johansen co-integration test result

\begin{tabular}{|c|c|c|c|c|}
\hline \multicolumn{5}{|c|}{ Unrestricted Cointegration Rank Test (Trace) } \\
\hline Hypothesized & & Trace & 0.05 & \\
\hline No. of CE(s) & Eigenvalue & Statistic & Critical Value & Prob.** \\
\hline None * & 0.796739 & 167.3638 & 95.75366 & 0.0000 \\
\hline At most $1 *$ & 0.725717 & 100.4467 & 69.81889 & 0.0000 \\
\hline At most 2 & 0.419412 & 46.11563 & 47.85613 & 0.0722 \\
\hline At most 3 & 0.298263 & 23.27961 & 29.79707 & 0.2326 \\
\hline At most 4 & 0.181208 & 8.403343 & 15.49471 & 0.4233 \\
\hline At most 5 & 0.000154 & 0.006489 & 3.841466 & 0.9352 \\
\hline \multicolumn{5}{|c|}{ Unrestricted Cointegration Rank Test (Maximum Eigenvalue) } \\
\hline Hypothesized & & Max-Eigen & 0.05 & \\
\hline No. of $\mathrm{CE}(\mathrm{s})$ & Eigenvalue & Statistic & Critical Value & Prob.** \\
\hline None * & 0.796739 & 66.91712 & 40.07757 & 0.0000 \\
\hline At most $1 *$ & 0.725717 & 54.33105 & 33.87687 & 0.0001 \\
\hline At most 2 & 0.419412 & 22.83601 & 27.58434 & 0.1806 \\
\hline
\end{tabular}




\begin{tabular}{|c|c|c|c|c|}
\hline At most 3 & 0.298263 & 14.87627 & 21.13162 & 0.2976 \\
\hline At most 4 & 0.181208 & 8.396855 & 14.26460 & 0.3398 \\
\hline At most 5 & 0.000154 & 0.006489 & 3.841466 & 0.9352 \\
\hline
\end{tabular}

From the above table, since the trace statistics of 167.3638 and 100.4467 are greater than the critical value of 95.75366 and 69.81889 , the study conclude that there is presence of long run relationship between foreign direct investment and economic growth in Nigeria. This is supported by the max-eigen statistics of 66.91712 and 54.33105 which are greater than their respective critical value of 40.07757 and 33.87687.

\subsection{Granger Causality Based on VECM Results}

Having established the presence of co-integration, the study proceeded to test for causality using vector error correction model techniques. The results of the test are presented in Table 3 below.

Table 3. Granger causality test result

\begin{tabular}{lccc}
\hline Variable & Lag length & Short run causation F-statistics & Long run causation t-statistics of ECT ${ }_{-1}$ \\
\hline GDP does not Granger cause FDI & 1 & $23.46505^{*}$ & $2.93958^{*}$ \\
FDI does not Granger cause GDP & 1 & $4.248796^{*}$ & 1.09856 \\
HMC does not Granger cause GDP & 1 & $6.627010^{*}$ & 0.99042 \\
ETR does not Granger cause GDP & 1 & 1.227871 & -0.74136 \\
CONS does not Granger cause GDP & 1 & $24.58003^{*}$ & $6.78464^{*}$ \\
OPN does not Granger cause GDP & 1 & 1.412062 & -0.33279 \\
Critical values at 5\% level of significance & & 2.042 & 2.53 \\
\hline
\end{tabular}

Note. * indicates significance at 5 percent level.

Source: Researcher's computation, 2015 using E-view 7.0.

The F-statistic shows the short run causation while the t-statistic of the lagged ECT indicates long run causation. The study finds a bi-directional relationship between FDI and economic growth in the short-run. It equally indicated that economic growth granger cause FDI in both short run and long run. Also, causality runs from human capital to foreign direct investment in the short run and construction expenditure cause increase in economic growth both in the short run and long run while electricity supply and openness to trade do not exhibit any causation.

\section{Discussion}

The study shows presence of bi--directional relationship between economic growth and FDI as indicated by Abdus (2009), Muhammad, Faiz, and Amir (2010), Nabila, Samia, and Hafeez (2011), Innocent et al. (2012) and Okon, Augustine, and Chikwu (2012). This finding contradict Magnus and Fosu (2007), Sumei and Selvanathan (2008), Olusegun (2009), Ajibola and Olufemi (2011), Gravwoke and Eskanake (2012), Williams (2012), Abdulahi, Aliero, and Yusuf (2012) who discovered that FDI granger cause economic growth. Also, the study is not in tandem with studies such Abdus (2009), Ogiagah, Paker, and Shaib (2011) and Ogundipe and Aworinde (2011) who posited that economic growth granger cause FDI. The findings of the study indicated that FDI and economic growth reinforce each other only in the short run. The study also shows that economic growth cause FDI both in the short and long run and long run while FDI granger cause economic growth only in the short run in Nigeria.

The fact that both the study established a bi-directional relationship between foreign direct investment and economic growth is an indication that both FDI and economic growth impact on each other. This proved that classical theory of FDI hold for Nigeria. The study notes further that in the short run, human capital expenditure granger causes economic growth (GDP) while expenditure on construction granger cause economic growth in both short run and long run. Electricity supply and level of trade openness do not exhibit any causation with economic growth in Nigeria. This might be due to the neglect of power sector which made it almost impossible to have regular power supply since oil boom of 1970s in Nigeria. This has impacted negatively on the economy and made it elusive to attract adequate FDI that will trickle down to the economy such that poverty and unemployment rate will be reduced. The insignificance of the ECT of the electric consumption model justifies that it has not being responsible for economic growth of Nigeria but can adjust to impact on economic growth in the long run as indicated by its negativity. 
The empirical evidence of short run bi-directional causality in Nigeria indicate that rapid economic growth has accelerated the inflow of FDI as well as increase inward flow of FDI has improved economic growth in Nigeria. Since the inception of stable government from 1999, there have been swift structural changes within the Nigerian economy, which attracted FDI inflow. Furthermore, rapid economic growth, along with the rising per capital income in Nigeria, has strengthened business confidence for overseas investors investing in Nigeria. This is in line with the classical and new growth theories which posited that FDI has spillover effect on economic growth of any country.

\section{Conclusion and Recommendations}

The study established a bi-directional relationship between FDI and economic growth in the short run while uni-directional causality run from economic growth to FDI only in the long run. These are in line with classical and new growth theories. It further shows that human capital expenditure cause economic growth in the short run while construction expenditure cause economic growth in the short run and in the long run. Also, the study established evidence of long run relationship between FDI and economic growth in Nigeria. The results imply that the benefits from such investment would be greatly enhanced if the recipient country has high quality human capital and reliable infrastructural facilities such as electricity and good network of roads.

The study recommends the following suggestions with regards to two-way causation between FDI inflow and economic growth in Nigeria.

1) Government should embark on aggressive trade policy reforms that will adequate protect and promote foreign investment in Nigeria. This will create investors' confidence and lure them to invest in the country.

2) The negative impact of openness on economic growth as shown in the results of this analysis indicates the need to introduce mild openness to allow only the inflow of FDI that have the capacity to transfer knowledge and foreign technologies to the domestic entrepreneur.

3) Furthermore, the significance of the expenditure on human capital points to its importance on economic growth. Therefore, there is need to improve the quality of human capital that will be employed by multinational companies to enhance their productivity.

4) Government should reform the power sector to guarantee adequate electricity supply. This will create conducive environment for business which will invariably attract the inflow of FDI into the country.

5) Aggressive construction of infrastructural facility such as road should be facilitated and improved to ease the movement of goods. This will reduce the cost of doing business which will influence inflow of foreign direct investment in Nigeria.

\section{References}

Abdullahi, Y. Z., Aliero, H. M., \& Yusuf, M. A. (2012). Does FDI cause economic growth? Evidence from selected Countries in Africa and Asia. African Journal of Social Sciences, 2(4), 114-124. Retrieved from http://www.sachajournals.com/user/image/yahya2012vol4 ajss002.pdf

Abdus, S. (2009). Does FDI causes economic growth? Evidence from South East Asia and Latin America? Woodbury School of Business Working Paper 1-09. Retrieved from http://www.wbiconpro.com/242-Abdus.pdf

Ade, O. A., Babatunde, H., \& Awoniyi, M. A. (2011). Corruption, foreign direct investment and economic growth in Nigeria: An empirical investigation. Journal of Research in International Business Management, 1(9), 278-292. Retrieved from http://www.interesjournals.org/full-articles/corruption-foreign-direct-investment-and-economic-growth-in-n igeria-an-empirical-investigation.pdf?view=inline

Adegbemi, B. O. (2012). Foreign direct investments and economic growth in Nigeria: A disaggregated sector analysis. Journal of Economics and Sustainable Development, 13(10), 66-75. Retrieved from http://www.iiste.org/Journals/index.php/JEDS/article/view/2906

Adeleke, A. I. (2013). Introduction to macro-econometric modeling and model specification for the Nigeria economy. A paper presented at Centre for Econometric and Allied Research (CEAR), department of economics, University of Ibadan. Econometric workshop module IV, November 25-29.

Alfaro, L. (2003). Foreign direct Investment and growth: Does the sector matter? USA Harvard Business School. Retrieved from http://www.people.hbs.edu/lalfaro/fdisectorial.pdf

Babatunde, O. O., John, E. E., \& Samuel, O. O. (2012). Locational determinants of foreign direct investment in 
Nigeria. International Business Research, 5(4), 103-111. Retrieved from http://www.ccsenet.org/ibr

Bello, A., \& Adeniyi, O. (2010). FDI and the environment in developing economies: Evidence from Nigeria. Environmental Research Journal, 4(4), 291-297. http://dx.doi.org/10.3923/erj.2010.291.297

CBN. (2011). Central bank of Nigeria statistical bulletin, 2011.

Chakraborty, C., \& Nunnenkamp, P. (2008). Economic reforms, FDI, and economic growth in India: A sector level analysis. World Development, 36(7), 1192-1212. http://dx.doi.org/10.1016/j.worlddev.2007.06.014

Cortright, J. (2001). New growth theory, technology and learning: A practitioner guide. Review of Economic Development Literature and Practice, 4, US.

De Castro, S. (1998). Technology implications of new growth theory for the South. Cooperation South Journal, 2, 68-79.

Egwaikhide, C. I. (2012). The impact of foreign direct investment on Nigeria's economic growth; 1980-2009: Evidence from the Johansen's cointegration approach. International Journal of Business and Social Science, 3(6), 122-134. Retrieved from http://www.ijbssnet.com/../16.pdf

Eravwoke, K. E., \& Eshanake, S. J. (2012). Foreign direct Investment Granger and Nigerian growth. Journal of Innovative Research in Management and Humanities, 3(2), 132-139. Retrieved from /http://www.grpjournal.org/Journal/Category/JOIRMAH.aspx

Gao, T. (2005). Foreign direct investment and growth under economic integration. Journal of International Economics, 67, 157-174. http://dx.doi.org/10.1016/j.jinteco.2004.11.003

Gaurav, A., \& Mohd, A. K. (2011). Impact of FDI on GDP growth: A panel data study. European Journal of Scientific Research, 57(2), 257-264. Retrieved from http://www.eurojournals.com/ejsr.htm

Girma, S., \& Wakelin, K. (2000). Are there regional spillovers from FDI in the UK? Leverhulme Center Research Paper 2000/ 16, The University of Nottingham.

Girma, S., Kneller, R., \& Pisu, M. (2003). Do exporters have anything to learn from foreign multinationals? Leverhulme Center Research Paper 2003/22, The University of Nottingham.

Gorg, H., \& Greenaway, D. (2001). Foreign direct investment and intra-industry spillovers: A review of the literature. Leverhulme Center Research Paper 2001/37.

Gorg, H., \& Strobl, E. (2002). Multinational companies and indigenous development: An empirical analysis. European Economic Review, 46, 1305-1322. http://dx.doi.org/10.1016/S0014-2921(01)00146-5

IMF. (2012). World outlook. Global Financial Magazine.

Innocent, C. O., Nkechinyere, R. U., Ebele, N., \& Nzeribe, G. (2012). Economic growth and foreign direct investment in Nigeria: An empirical investigation. Journal of Economics and Sustainable Development, 3(13), 34-40. Retrieved from http://www.iosrjournals .org/iosr-jhss/papers/Vol14-issue1/A01410109.pdf?id=6722

Lensink, R., \& Morrissey, O. (2001). Foreign direct investment: Flows, volatility and growth. Paper presented at the Development Economics Study Group Conference, University of Nottingham, UK, 5-7 April.

Li, X., \& Liu, X. (2005). Foreign direct investment and economic growth: An increasingly endogenous relationship. World Development, 33(3), 393-407. http://dx.doi.org/10.1016/j.worlddev.2004.11.001

Magnus, J. F., \& Fosu, E. O. (2007). Bivariate causality analysis between FDI inflows and economic growth in Ghana. MPRA Paper No. 351.

Masih, A. M. M., \& Masih, R. (1996). Electricity consumption, real income and temporal causality: Results from a multi-country study based on co-integration and error correction modeling techniques. Energy Economics, 18, 165-183. http://dx.doi.org/10.1016/0140-9883(96)00009-6

Masih, A. M. M., \& Masih, R. (1997). On temporal causality between electricity consumption, real income and prices: Some new evidence from Asian energy dependent Nics based on multivariate co-integration and error correction modeling approach. Journal of Policy Modeling, 19, 417-440. http://dx.doi.org/10.1016/S0161-8938(96)00063-4

Masih, A. M. M., \& Masih, R. (1998). Multivariate co-integrated modeling approach to testing temporal causality between energy consumption, real income and prices with an approach to Asian LDCs. Journal of Applied Economics, 30(10), 1287-1298. http://dx.doi.org/10.1080/000368498324904 
Meier, G. M., \& Rauch, J. E. (1995). Leading issues in economic development. New York: Oxford University Press.

Mody, A. (2004). Is FDI integrating the world economy? World Economy, 27(8), 1195-1222. http://dx.doi.org/10.1111/j.1467-9701.2004.00647.x

Muhammad, S. I., Faiz, M. S., \& Amir, H. S. (2010). Causality relationship between foreign direct investment, trade and economic growth in Pakistan. Asian Social Science, 6(9), 82-89. Retrieved from http://www.ccsenet.org/ass

Nabila, A., Samia, N., \& Hafeez, R. (2011). Relationship between FDI and economic growth in selected Asian countries: A panel data analysis. Review of Economics and Finance, 84-96. Retrieved from http://www.bapress.ca/Journal-6/Relationship\%20between\%20FDI\%20and\%20Economic\%20Growth\%20i n\%20Selected\%20Asian\%20Countries--A\%20Panel \%20Data\%20Analysis.pdf

Ogiagah, Z. M., Parker, I. F., \& Shaib, I. O. (2011). Co-integration analysis of foreign direct investment inflow and development in Nigeria. Developing Country Studies, 1(1), 56-66. Retrieved from http://www.iiste.org

Ogundipe, M. A., \& Aworinde, O. B. (2011). An analysis of causality between economic growth and foreign direct investment in pre-and post-deregulated Nigerian economy (1970-2007). European Journal of Scientific Research, 53(3), 317-325.

Okon, J. U., Augustine, O. J., \& Chuku, A. C. (2012). Foreign direct investment and economic growth in Nigeria: An analysis of the endogenous effects. Current Research Journal of Economic Theory, 4(3), 53-66.

Olusegun, O., Oluwatosin, A., \& Ayoola, O. (2009). FDI, trade openness and growth in Nigeria. Journal of Economic Theory, 3(2), 13-18. $\quad$ Retrieved from http://docsdrive.com/pdfs/medwelljournals/jeth/2009/13-18.pdf

Oyatoye, E. O., Arogundade, K. K., Adebisi, S. O., \& Oluwakayode, E. F. (2011). Foreign direct investment, export and economic growth in Nigeria. European Journal of Humanities and Social Sciences, 2(1), 66-86. Retrieved from http://www.Journa lsbank.com/ejhss_2_1.pdf

Philip, I. N., Ajibola, M. A., \& Olufemi. M. S. (2011). Causal relationships between financial development, foreign direct investment and economic growth: The case of Nigeria. International Journal of Business Administration, 2(4), 93-102. Retrieved from http://www.sciedu.ca/journal/index.php/ijba/article/viewFile/564/272

Samuel, J. E., \& Victor, E. O. (2012). Foreign direct investment in Nigeria: The roles of real effective exchange rate, market size, openness and inflation. European Journal of Economics, Finance and Administrative Sciences, 53, 106-113. Retrieved from http://www.eurojournals.com/EJEFAS.htm

Seid, S. (2002). Global regulation of foreign direct investment. England: Ashgate Publishers.

Shan, J., Tian, G. G., \& Sun, F. (1997). The FDI-led growth hypothesis: Further econometric evidence from China. Research School of Pacific and Asian Studies, Working Paper 97/2, Australian National University, Canberra.

Sumei, T., Selvanathan, E. A., \& Selvanathan, S. (2008). Foreign direct investment, domestic investment, and economic growth in China: A time series analysis. UNU-WIDER Research Paper, No. 2008/19.

UNCTAD. (1999). World investment report: Promoting linkages. New York, United Nations.

UNCTAD. (2015). World investment report. New York, United Nations.

William, A. (2012). On the nature of the causal relationships between foreign direct investment, GDP and exports in South Africa. Journal of International Development, 1-15. Retrieved from http://www.onlinelibrary.wiley.com/doi/10.1002/jid.2892/pdf

Yaqub, J. O., Adam, S., \& Jimoh, A. (2013). Foreign direct investment and economic growth in Nigeria: An empirical analysis. American Academic and Scholarly Research Journal, 5(1), 74-82. Retrieved from http://naturalspublishing.com/files/published/764sd176i7h3n3.pdf

Zafar, A. S. (2013). A causal relationship between FDI inflows and export: The case of India. Journal of Economics and Sustainable Development, 4(2). Retrieved from http://www.iiste.org/Journals/index.php/JEDS/article/download/4118/4137 


\section{Appendix}

\section{Variables Used for Analysis}

\begin{tabular}{|c|c|c|c|c|c|c|}
\hline Year & $\begin{array}{c}\text { GDP at Current } \\
\text { Basic Prices (GDP) }\end{array}$ & $\begin{array}{l}\text { Inflow of } \\
\text { FDI (FDI) }\end{array}$ & $\begin{array}{c}\text { Recurrent Expenditure } \\
\text { on Heath and Education } \\
(\mathrm{HMC})\end{array}$ & $\begin{array}{c}\text { Percentage of Electricity } \\
\text { Consumption (Megawatt } \\
\text { per Hour) (ETR) }\end{array}$ & $\begin{array}{c}\text { Construction } \\
\text { Expenditure (CONS) }\end{array}$ & Openness (OPN) \\
\hline 1970 & $5,281.1$ & 251 & 36.92 & 37.1 & 14.28 & 0.4787 \\
\hline 1971 & $6,650.9$ & 489.6 & 16.58 & 36.5 & 15.6 & 0.5512 \\
\hline 1972 & $7,187.5$ & 432.8 & 19.49 & 34.5 & 14.91 & 0.5368 \\
\hline 1973 & $8,630.5$ & 577.8 & 23.02 & 37.2 & 17.65 & 0.6699 \\
\hline 1974 & $18,823.1$ & 507.1 & 51.27 & 38.7 & 17.24 & 0.708 \\
\hline 1975 & $21,475.2$ & 757.4 & 162.61 & 37.1 & 31.97 & 0.632 \\
\hline 1976 & $26,655.8$ & 521.1 & 383.26 & 42 & 46.65 & 0.6997 \\
\hline 1977 & $31,520.3$ & 717.3 & 232.19 & 41.9 & 51.07 & 0.7092 \\
\hline 1978 & $34,540.1$ & 664.7 & 207.77 & 77.9 & 33.61 & 0.5889 \\
\hline 1979 & $41,974.7$ & 704 & 166.55 & 48.2 & 1.89 & 0.6945 \\
\hline 1980 & $49,632.3$ & 786.4 & 208.6 & 45.3 & 46.03 & 0.755 \\
\hline 1981 & $47,619.7$ & 584.9 & 249.89 & 48.4 & 96.66 & 0.7326 \\
\hline 1982 & $49,069.3$ & 2193.4 & 283.88 & 50.6 & 109.81 & 0.554 \\
\hline 1983 & $53,107.4$ & 1673.6 & 244.94 & 51.4 & 94.75 & 0.4502 \\
\hline 1984 & $59,622.5$ & 1385.3 & 300.45 & 52.2 & 116.23 & 0.4252 \\
\hline 1985 & $67,908.6$ & 1423.5 & 390.62 & 51.9 & 151.11 & 0.4492 \\
\hline 1986 & $69,147.0$ & 4024 & 396.83 & 56.6 & 153.51 & 0.3446 \\
\hline 1987 & $105,222.8$ & 5110.8 & 266.32 & 54.9 & 409.08 & 0.7468 \\
\hline 1988 & $139,085.3$ & 6236.7 & 1881.6 & 52 & 693.6 & 0.6027 \\
\hline 1989 & $216,797.5$ & 4692.7 & 3587.1 & 53.6 & 491 & 0.6771 \\
\hline 1990 & $267,550.0$ & 10450.2 & 2903.5 & 50.2 & 634.4 & 0.9923 \\
\hline 1991 & $312,139.7$ & 5610.2 & 1874.5 & 48.5 & 406.8 & 1.0654 \\
\hline 1992 & $532,613.8$ & 11730.7 & 441.46 & 48.5 & 1140.87 & 1.0409 \\
\hline 1993 & $683,869.8$ & 42624.9 & 12753.98 & 51.9 & 2323.46 & 0.882 \\
\hline 1994 & $899,863.2$ & 7825.5 & 9476.72 & 52.5 & 1144.09 & 0.6389 \\
\hline 1995 & $1,933,211.6$ & 55999.3 & 13067.1 & 51.3 & 1699.1 & 1.3741 \\
\hline 1996 & $2,702,719.1$ & 5672.9 & 14519.86 & 50.1 & 932.6 & 1.1772 \\
\hline 1997 & $2,801,972.6$ & 10004 & 18744.64 & 50.3 & 1807.98 & 1.1881 \\
\hline 1998 & $2,708,430.9$ & 32434.5 & 18331.76 & 51.4 & 5634.62 & 0.8643 \\
\hline 1999 & $3,194,015.0$ & 4035.5 & 60249.42 & 51.5 & 16638.77 & 1.0145 \\
\hline 2000 & $4,582,127.3$ & 16435.5 & 73174.72 & 51 & 4991.09 & 1.0642 \\
\hline 2001 & $4,725,086.0$ & 4937 & 64404.87 & 51.1 & 7202.04 & 1.0781 \\
\hline 2002 & $6,912,381.3$ & 8988.5 & 121152.3 & 59.2 & 7452.14 & 0.2235 \\
\hline 2003 & $8,487,031.6$ & 13531.2 & 98410.13 & 59.6 & 16951.37 & 0.9728 \\
\hline 2004 & $11,411,066.9$ & 20064.4 & 110721.8 & 51.4 & 16897.01 & 0.9809 \\
\hline 2005 & $14,572,239.1$ & 26083.7 & 138456.7 & 55.5 & 17914.96 & 1.1868 \\
\hline 2006 & $18,564,594.7$ & 41734 & 145981.1 & 14.9 & 20100 & 0.9565 \\
\hline 2007 & $20,657,317.7$ & 634251.1 & 179819.4 & 19.26 & 71500 & 0.9939 \\
\hline 2008 & $24,296,329.3$ & 672202.6 & 262200 & 18.14 & 94500 & 1.0501 \\
\hline 2009 & $24,794,238.7$ & 718977.3 & 227359.2 & 17.66 & 80630 & 0.8799 \\
\hline 2010 & $29,205,783.00$ & 776332.2 & 261260 & 20.38 & 138050 & 1.0298 \\
\hline 2011 & $63,258,580.00$ & 834161.8 & 244309.6 & 20.38 & 109340 & 0.6541 \\
\hline 2012 & $71,186,530.0$ & 888893 & 252784.8 & 18.14 & 123695 & 0.5947 \\
\hline 2013 & $80,222,130.00$ & 861527.4 & 248547.2 & 17.66 & 130872.5 & 0.6244 \\
\hline
\end{tabular}

Source: CBN Statistical Bulletin, 2009, 2010 and 2013, IMF 2011 and International Energy Statistics, 2012.

\section{Copyrights}

Copyright for this article is retained by the author(s), with first publication rights granted to the journal.

This is an open-access article distributed under the terms and conditions of the Creative Commons Attribution license (http://creativecommons.org/licenses/by/3.0/). 